\title{
The British Gendarmerie Mission in Albania, 1925-1938
}

Helian Demiri PhD. Cand.

"Aleksander Xhuvani" University, Albania

\begin{abstract}
By 1925 Albania was striving for its existence as political and social chaos prevailed in the country. Once returned to power Ahmet Zog pursued an ambitious goal and sought to create a united and stable Albanian state. To this end, he believed the re-organization of an efficient gendarmerie would be the most urgent question he needed to address. In order to establish a neutral and effective force he believed the most appropriate choice was to hire British officers. This proved to be a complicated task as HMG did not want to interfere in Albanian internal affairs. However, they had long been champions of Albania's independence and territorial integrity, considering it the key to preserving peace in the Balkans. Integrating these two viewpoints the British will come up with an ad hoc solution. The gendarmerie mission in Albania will be instructed and trained by ex-British officers with no official ties to HMG. They will be hired as private individuals in order to avoid the resentment of Italy for interfering in Albania's internal questions. The British officers will remain in charge of the Albanian gendarmerie from 1925-1938. Their mission is an example of Great Britain's contribution in giving Albania a chance to consolidate its independence. On the other hand, the British official disentanglement with the scheme was part of the strategy to appease Italy and avoid friction between the two powers. Although faced with various difficulties, the gendarmerie mission managed to slow down the Italian penetration in Albania and became a stability factor in the country.
\end{abstract}

Keywords: Albania, Zog, gendarmerie, Britain, Italy

\section{Introduction}

After WWI, brigandage and lawlessness were commonplace in Albania and made the country lag behind in stability and economic progress. Moreover, continuous uprisings and revolutions caused tremendous political upheaval which made the situation worse. There was an urgent need to ensure security and stability otherwise the country would be trapped in a vicious circle.

After his return to power, at Christmas Eve 1924, through a counter-revolution, Ahmet Zog started to take several measures which aimed at putting Albania on its feet. As he had promised earlier, Zog suppressed the army, believing this would bring stability and internal order. During the few years of Albania's independence, the army had been the greatest danger to central power, as it had failed to defend the country's borders which in its turn had led to troubles with the neighbors and had seriously threatened peace in the region. In addition, the army officers "spent their time plotting political intrigues"1, which had produced a number of coups. It was obvious that so far it had weakened the state's integrity rather than protect it. Zog planned to change all this by substituting the army for a small and efficient gendarmerie

This article deals with Ahmet Zog's attempts to establish a functional gendarmerie which would ensure the preservation of law and order in Albania. As Zog himself explained 'the keystone of the arch of his building was reorganization of the gendarmerie.'2 For this purpose, he would insist on having as inspectors, to organize the force, British officers. The attempt to involve Britain in the internal affairs of Albania will have implications which are representative of the weak international position of Albania in the 1920's and a reflection of the, rivalry, prejudice and fear that existed among the European Powers in the interwar years.

\footnotetext{
${ }^{1}$ Bernd Fischer, King Zog and the struggle for stability in Albania, Çabej, Tirana 2004. p. 88.

2 Jason Tomes, King Zog, self-made monarch of Albania. Sutton Publishing Limited, London. 2003. p. 76.
} 
Britain was a disinterested power in the internal developments of the Balkans but at the same time, its foreign policy's cornerstone was the preservation of peace and the status quo. In the case of the Albanian gendarmerie mission, Britain found it hard to integrate these two objectives, although not without success. One of the main obstacles in implementing this scheme was the Italian resentment towards any interference from another country in the internal issues of Albania. Moreover, Britain and the other Great Powers had recognized Italy's special interests in Albania with the resolution of 9 November 1921. British engagement with the gendarmerie scheme could be interpreted as a breach of this resolution.

At the same time, Britain was considered 'the sponsor of Albania's independence'1 and insisted in giving the country 'a fair start'2. But by 1925 , the Italian attempts to gain predominance in Albania were threatening her integrity and independence. That was something that the British government wanted to avoid.

In March 1925 in Albania arrived 9 ex-British officers with the task of re-organizing the gendarmerie. HMG did not take any responsibility for their mission and they were considered private British subjects hired by the Albanian government. Thus, the Albanian gendarmerie was run by ex-British officers from 1925-1938 becoming an example of Great Britain's contribution in giving Albania a chance to consolidate its independence. On the other hand, the British official disentanglement with the scheme was part of the strategy to appease Italy and avoid friction between the two powers. Although faced with various difficulties, the gendarmerie mission managed to slow down the Italian penetration in Albania and became a stability factor in the country, thus partly fulfilling the objectives set since when it was founded.

\section{Albanian attempts to establish a gendarmerie mission organized by British officers}

In January 1925, following the example of western countries, similar in size to Albania, such as Switzerland, Zog established a small gendarmerie force to safeguard law and order. Such a police force had several advantages to maintaining an army. It was obvious that Albania could not defend itself from possible foreign attacks as all the potential countries that might want to invade it possessed a superior military force. Therefore, the army was a waste of money and a burden to the state budget. Moreover, this change would reassure the neighbors that Albania had no irredentist intentions dispelling prejudice and tension that already existed. However, the gendarmerie needed to be organized and trained as a modern institution to fulfill the needs of the young state and this required experience and expertise which Albania lacked.

The engagement of British officers as inspectors for the Albanian gendarmerie was thought to be the right solution. As Vickers puts it: "In comparison with other police forces, the British police were thought to be relatively honest, reliable and loyal."3 Moreover, the presence of British officers in Albania would remove the Italian and Yugoslav suspicions that Zog favored one over the other, especially when earlier there had been rumors that "the organization of the gendarmerie would be trusted to a Yugoslav officer"4 Therefore, Zog approached Great Britain for support and assistance.

In January 1925, under the instructions of Zog, the British Colonel W.F. Stirling, who had been adviser for the Albanian Ministry of the Interior since 1923, headed to England with the aim of recruiting a small number of officers who under his command would deal with the re-organization of the Albanian gendarmerie. ${ }^{5}$ Through his personal contacts in England, he had advertised this employment opportunity, and even before his arrival in London the War Office started to get applications from interested officers. ${ }^{6}$ Not being sure what to do, they turned to Foreign Office for advice. At a time when, Zog's scheme was simple and straightforward, the wide range interests of Great Britain made it a complicated matter.

The main British interest in the 1920's was the maintenance of the global balance of power and preservation of the status quo and peace. ${ }^{7}$ While with regards to the Balkans, Austen Chamberlain, the British Foreign Secretary, declared that the lack of immediate British interests in the region precluded a necessity to plump for "any particular solution of any of its

\footnotetext{
1 TNA FO 37111206 C 8933/391/90 Foreign Office Memorandum, British policy in Albania, 3 August 1926.

2 W.N.Medlicott, Douglas Dakin, Gillian Bennett (eds.) Documents on British foreign policy, 1919-1939. first series, vol. xxii, no. 609. HMSO Press, Edinburgh 1980.

${ }^{3}$ Miranda Vickers, The Albanians, a modern history. MPG Books, London 1999. p. 119.

4 Pietro Pastorelli, La penetrazione italiana in Albania (Gli accordi economici italo-albanesi del marzo 1925). Rivista di Studi Politici Internazionali, vol 33, no. 1. January-March 1966. p. 13.

5 TNA FO 37110656 C 1208/763/90 Eyres to FO, Re-organization of Albanian gendarmerie, 26 January 1925.

6 TNA FO 37110656 C 1208/763/90 Minutes by Nicolson, 28 January 1925.

${ }^{7}$ Michael Dockrill and Brian McKercher (eds.) Diplomacy and world power. Studies in British Foreign Policy, 1890-1950. Brian

McKercher, Old diplomacy and new: the Foreign Office and foreign policy, 1919-1939. Cambridge University Press, 1996. p. 110
} 
many problems"1. Obviously, there was a contradiction in the two attitudes. If the many problems of the region were not given a solution, friction among neighbors would lead to trouble and possibly war. The balance of power in the interwar years was so fragile that any disturbance, no matter how small, could have unpredictable results. Thus the Foreign Office found itself in front of a delicate situation. Should Britain interfere in Albania in order to avoid troubles in the region and contribute to preserving peace and the status quo, or should it remain neutral and not meddle in Balkan affairs?

There were several elements that needed to be considered before coming to a final decision. Any British approach towards Albania would be resented by Italy and this could weaken the ties between the two Great Powers. This was the last thing that Chamberlain wanted, especially after having established promising personal relations with Mussolini. ${ }^{2}$

At the same time, when the issue of the gendarmerie mission was being discussed in the FO, the British were in another dispute with Italy over Albania. In order to raise money he badly needed to consolidate the state administration, Zog had offered a number of economic concessions to foreign companies. Britain and Italy were competing for the Albanian oil prospecting rights which they both considered as lucrative. The British had been trying to resolve this issue through an understanding with the Italians, but the gendarmerie question would make a settlement improbable. In the instructions for Harry Eyres, the British Minister in Albania, the FO officials underlined that: "the matter is complicated on account of question of petroleum and tobacco concessions, both disliked by Italians, being raised in an acute form at the same time. These two questions may very likely prove capable of satisfactory arrangement if not treated in atmosphere of tension with Italy over gendarmerie. ${ }^{3}$ As Harold Nicolson put it, the British government "did not wish, even in an indirect manner to be concerned in the internal affairs of Albania" and "would not be in favor of the proposal." When informed of the British skepticism about the scheme, Zog felt disappointed. He was convinced that "there was no rational alternative to his plan as Albanians were kittle cattle to deal with and Englishmen alone had the requisite racial characteristics"5

However, in the FO there were also officials who thought differently. Eyre Crowe, the Permanent Under-Secretary, believed that a strong and efficient gendarmerie was the only chance Albania had to consolidate its independence and, preserve law and order as a precondition for the country's development. Although, the British government had done nothing to promote the scheme, if the British refused such a proposal, which for Albania was a "matter of life and death" and was considered "really the last chance" 6 , only because the Italians were sensitive about it, this would be a heavy moral burden for them. In Crowe's point of view, this was an exaggerated whim of Italy, which "prefers that Albania should go to pieces rather than British officers should be employed to keep her together."

Britain needed to find a middle course solution to the Albanian gendarmerie question. Howard Smith was convinced that: "if Zog shows some patience,...he will get his scheme through." 8 Whereas a month later, it was the same Smith who reported that "nine officers that colonel Stirling tried to hire are already in Albania. ${ }^{9}$

Even without the official involvement of the British government, the scheme for the re-organization and training of the Albanian gendarmerie by British officers had gone through. "As Chamberlain once noted: "in difficult times there is no more common ending to a political discussion between Englishmen than the phrase: 'Well, I suppose we shall muddle through somehow.'10 Colonel Stirling had not been put obstacles but had not received official support either. This way HMG did not take any official responsibility, avoiding Italian resentment, and at the same time, gave Albania a chance to establish order

\footnotetext{
1 TNA FO 37110695 C 6952/251/62 Minutes by Chamberlain, 21 May 1925.

2 Peter Edwards, The Austen Chamberlain Meetings. The Historical Journal, vol. 14. No 1. March 1971. pp. 153-164.

3 TNA FO 37110656 C 2063/763/90 FO to Eyres, 13 February 1925.

4 TNA FO 37110656 C 1208/763/90 Minutes by Nicolson, 28 January 1925.

5 TNA FO 37110656 C 2985/763/90 Eyres to FO, 17 February 1925.

6 TNA FO 37110656 C 2063/763/90 Minutes by Eyre Crowe, 13 February 1925.

7 TNA FO 37110656 C 1570/763/90 Minutes by Eyre Crowe, 3 February 1925.

8 TNA FO 37110656 C 2985/763/90 Minutes by Howard Smith, 4 March 1925.

9 TNA FO 37110656 C 4748/763/90 Memorandum by Howard Smith, 2 April 1925.

* There were nine ex-British officers engaged in the re-organization of Albanian gendarmerie. To administer the force more effectively, the country was divided in four zones with one inspector and a deputy each. Lieutenant Colonel Stirling who held the post of general inspector was located in Tirana. Major Palmer and captain Barbrook were responsible for the area of Tirana; lieutenant colonel Richey and captain Hunt responsible for Shkodra; major Sutton and lieutenant colonel Macmullen responsible for Peshkopia; major Jackson and captain Reypert responsible for the region of Saranda.

${ }^{10}$ Austen Chamberlain, The Permanent Bases of British Foreign Policy. Foreign Affairs, vol.9, no. 4, July 1931. p. 535-36.
} 
and law, by employing ex-British officers in a private capacity. The only thing left to do was to see how this experiment would work, although it was known that its success was not an easy task.

\section{The reasons for the successes and failures of the gendarmerie mission}

For little more than one year the gendarmerie mission led by Colonel Stirling made little progress. There were a number of organizational and personal issues that contributed to this. ${ }^{1}$ However, Zog was determined to continue with the scheme and decided to trust this task to another British officer. In October 1926, General Jocelyn Percy arrived in Albania and was appointed Inspector General of the gendarmerie. Even though, HMG was not involved in the selection of the General, it had been Harry Eyres, the now retired British diplomat who had negotiated his employment. ${ }^{2}$ Seeds, the British minister in Albania declared that "for however undesirable the engagement of these officers may rightly be in the opinion of HMG, a collapse of the scheme ... would be most regrettable from the point of view of British prestige." ${ }^{3}$ However, the lack of cooperation and support from the Albanian officials and the Italian intrigues to impede and denigrate the gendarmerie scheme, on several occasions put into question its continuity.

As soon as he took the post of inspector-general, Percy implemented several substantial changes to increase the force's effectiveness and prevent the Italian penetration in Albania. He reduced the force from 3000 men to 2300 making it more manageable and efficient. Percy introduced a rotation system for his inspectors so that they would be always active and not establish personal ties in the regions they covered. He was responsible directly to president Zog, thus avoiding obstacles which in the past had been created by the lack of ability and negligence of the Albanian officials. All these changes were highly appreciated by HMG who considered the gendarmerie "indispensable for policing the country districts by small groups in a manner for which the army is entirely unfitted..."4

Moreover, the force was a crucial instrument in balancing the Italian influence in Albania and served to preserve peace and tranquility. Seeds reported that: "British prestige and reputation for impartiality, stands high and while they remain here the officers will produce a soothing moral effect on Albanians inclined to chafe at what seems a complete Italianisation of their country."

Despite the difficulties, General Percy slowly took the mission forward. In the north, the most troublesome area of the country, he was a well known and liked figure and "the stream of Albanian officers coming to the General's office at the Prefecture in Scutari to obtain action and decisions on points at issue, was a striking testimony to the prestige which he and his staff were acquiring."6

The work of the General and his officers was so impressive and important that in 1928 they were considered a factor contributing to preserving peace in the Balkans. The Yugoslav minister in Albania, Mihaillovic, in a conversation with Hodgson, the British Minister in Albania, declared that: "the British officers now in the country were up to their work and of tried neutrality. It would be a bad day for Yugoslavia were they to be withdrawn and the frontier exposed to be the scene of unending incidents which any troublous faction could create at will and in which Yugoslavia would invariably play the role of villain"7

However, General Percy held the control of the gendarmerie at a time when having results was a difficult task. On several occasions the force was faced with insurmountable difficulties which put in doubt the success and continuation of the mission. The most delicate issue was the lack of financial support which impeded the implementation of substantial reforms. The amount of money available to meet the needs of various state departments was small and there was a harsh competition to get it. In view of the amount finally placed at his disposal general Percy had been obliged to make various modifications in his intended program. The pay of the men had had to be reduces, effectives cut down and projected

\footnotetext{
1 For more details see: Simon Martin, The Gendarmerie Mission in Albania, 1925-38: A move on the English chess board? Contemporary European History, vol. 7, no. 2. July 1998. pp. 143-159.

2 TNA FO 37112068 C 5387/787/90 Minutes by Harvey, 17 June 1927.

3 TNA FO 37111209 C 11060/1077/90 Seeds to Chamberlain, 5 October 1926.

4 TNA FO 37112068 C 3905/787/90 Seeds to Chamberlain, 19 April 1927.

5 lbid.

6 TNA FO 37112069 C 8803/946/90 Wyndham to Harvey, 20 October 1927.

7 TNA FO 37112845 C 5992/1090/90 Hodgson to A.Chamberlain, 27 July, 1928.
} 
improvements in transport arraignments sacrificed. Hodgson reported for the FO that: "The day when an efficient gendarmerie will be created in Albania is not yet in sight. ${ }^{1}$

Another obstacle in the work of the gendarmerie was also the mentality and attitude of the Albanian officials. Politicians would interfere in the appointment or promotion of the gendarmerie's officers making the force lack professionalism. It was also common for the gendarmes to receive their salaries several months in arrears therefore bribes and abuses were considered acceptable. General Percy by his repeated threats of resignation followed by no sequel, had so weakened his own position that no pressure he could bring to bear was likely to be effective. It was clear that the Albanians were using the British officers as: "a very convenient screen behind which they can hide the vices of their administration." ${ }^{2}$ Was the British mission to withdraw from Albania to avoid disgrace?

Even though, this was a matter of prestige, British diplomacy had to take other developments into account before deciding the course of their policy in relation to Albanian gendarmerie. In 1931, Italy had started a new attempt to advance its penetration in Albania. The difficult economic situation of the country gave Italy a good chance that in exchange for a financial loan, it could impose political conditions that restricted the independence of the country. The Italians suggested that Albania should be given a loan of 10 million gold francs a year, on condition that it would continue to spend 15 million gold francs to buy arms and ammunition and recognize Italy the right to control its spending. Practically, this "was nothing but an attempt to turn the Albanian army into a mercenary force paid by Italy." 3 In order to avoid such an eventuality, the British considered as crucial for Albania's independence to remind King Zog "of the value in the long run, in his own interests of having a few neutral advisers"4 The British gendarmerie inspectors had already proved up to the task.

By 1934 the Italian government had intensified its forward policy in Albania aiming at taking full control of the country. The Italian actions convinced HMG that the Italian penetration in Albania did not aim at preserving peace in the region but seriously threatened it. That is why British diplomacy considered the gendarmerie mission as a valuable tool to check upon the Italian interference and that is why they insisted that the gendarmerie mission should go on. If before HMG were reluctant to get involved and concealed their attitude because of the Italian resentment, now it was clear that maintaining peace and counter balancing Italian influence was more important than preserving good relations with Italy. Thus, Hodgson explicitly stated to King Zog, the Foreign Secretary's view, that for HMG it was desirable "of his continuing to employ General Percy and the British officers under him as organizers of the Albanian gendarmerie. It was, too, preferable, on general grounds that the organization of the armed forces of this country should be entrusted to officers of two nationalities rather than that is should be in the hands of officers of one country only."

The British demand was in accordance with Zog's desire to resist the Italian control and have British support in it. Therefore, he acknowledged that "General Percy and his officers had rendered signal service to Albania and that he would try so to arrange matters that the contracts of the British officers were prolonged without delay." 6 That would put the Italians in front of a fait accompli. The official British support for the gendarmerie scheme made the British officers continue their mission for another four years.

\section{The epilogue of an experiment}

By 1938, with the international crises the European Powers were involved in, the British attention had moved away from the small country in the Balkans. King Zog had been unable to resist alone to the Italian pressure and they had managed to take control of all the state institutions, including the gendarmerie. As Ryan, the British Minister reported from Albania: "The officer commanding the gendarmerie has become devoted to Italians and that the second in command is in their pay." ${ }^{7}$ For HMG it did not matter anymore if the British officers left Albania. The fate of the small country could not influence the international peace any more. Britain had long started the preparations for war against Germany and the presence of its officers in Albania would only create troublesome complications with the Italians, at a time when the final configuration

\footnotetext{
1 TNA FO 37113562 C 3383/3383/90 Hodgson to Austen Chamberlain, 7 May 1929

2 TNA FO 37115148 C 4338/1053/90 Hodgson to A. Henderson, 16 June 1931.

${ }^{3}$ Bernd Fischer, King Zog and the struggle for stability in Albania, Çabej, Tirana 2004. f. 210.

4 TNA FO 37115149 C 123/123/90 Minutes by R.M.A Hankey, 21 January 1932.

5 TNA FO 37118339 R 6486/67/90 Hodgson to John Simon, 14 November 1934.

${ }^{6}$ Ibid.

7 TNA FO 37122308 R 1959/1575/90 Ryan to FO, 22 February 1938.
} 
of the Alliances had not been established. The FO concluded that they "would not be altogether sorry to see the disappearance of British subjects generally from the Albanian state service. Their position is anomalous and there is always the danger of their getting into difficulties from which we may have to extricate them at the cost possibly of direct friction with the Italians."

In September 1938, General Percy and the last three British officers under his command, were considered to have fulfilled their mission in Albania and had been asked to return home. Their performance had been praised and criticized, but by the time their mission was over General Percy and his assistants were considered "entirely as useful agents of British influence in Albania"2 And as David Funderburk puts it:

"The British ex-officers' contribution to the spread of English influence was considerable. The British mission, by instruction of the Albanian gendarmerie and the close relations between General Percy and King Zog, provided somewhat of a check to Italian ambitions. ....The British mission was indicative of the extension of British influence in Albania beyond political and economic relations." ${ }^{3}$

\section{References}

\section{Published Sources}

[1] Chamberlain, Austen. The Permanent Bases of British Foreign Policy. Foreign Affairs, vol.9, no. 4, July 1931. pp. 535-46.

[2] Dockrill, Michael and McKercher, Brian (eds.) Diplomacy and world power. Studies in British Foreign Policy, 1890-1950. Brian McKercher, Old diplomacy and new: the Foreign Office and foreign policy, 1919-1939. Cambridge University Press, 1996.

[3] Edwards, Peter. The Austen Chamberlain Meetings. The Historical Journal, vol. 14. No 1. March 1971. pp. 153164.

[4] Fischer, Bernd. King Zog and the struggle for stability in Albania, Çabej, Tirana 2004.

[5] Funderburk, David. Anglo-Albanian Relations, 1920-1939. Revue des Etudes Sud-Est Europeennes, t.XIII, 1975, no. 1.

[6] Martin, Simon. The Gendarmerie Mission in Albania, 1925-38: A move on the English chess board? Contemporary European History, vol. 7, no. 2. July 1998. pp. 143-159.

[7] Medlicott, W.N.; Dakin, Douglas; Bennett, Gillian (eds.) Documents on British foreign policy, 1919-1939. first series, vol. xxii. HMSO Press, Edinburgh 1980

[8] Pastorelli, Pietro. La penetrazione italiana in Albania (Gli accordi economici italo-albanesi del marzo 1925). Rivista di Studi Politici Internazionali, vol 33, no. 1. January-March 1966. pp. 8-60

[9] Tomes, Jason. King Zog, self-made monarch of Albania. Sutton Publishing Limited, London. 2003.

[10] Vickers, Miranda. The Albanians, a modern history. MPG Books, London 1999.

\section{Primary Sources:}

TNA FO 37111206 C 8933/391/90

TNA FO 37110656 C 1208/763/90

TNA FO 37110695 C 6952/251/62

TNA FO 37110656 C 2063/763/90

TNA FO 37110656 C 1208/763/90

TNA FO 37110656 C 2985/763/90

TNA FO 37110656 C 1570/763/90

\footnotetext{
1 TNA FO 37122308 R 1959/1575/90 Minutes by FO, 19 March 1938.

2 lbid.

${ }_{3}^{3}$ David Funderburk, Anglo-Albanian Relations, 1920-1939. Revue des Etudes Sud-Est Europeennes, t.XIII, 1975, no. 1. p. 120.
} 
TNA FO 37110656 C 2985/763/90

TNA FO 37110656 C 4748/763/90

TNA FO 37112068 C 5387/787/90

TNA FO 37111209 C 11060/1077/90

TNA FO 37112068 C 3905/787/90

TNA FO 37112069 C 8803/946/90

TNA FO 37112845 C 5992/1090/90

TNA FO 37113562 C 3383/3383/90

TNA FO 37115148 C 4338/1053/90

TNA FO 37115149 C 123/123/90

TNA FO 37118339 R 6486/67/90

TNA FO 37122308 R 1959/1575/90 